\title{
HUBUNGAN TINGKAT PENGETAHUAN IBU TENTANG GIZI DENGAN KEJADIAN KURANG ENERGI PROTEIN PADA ANAK USIA 2-5 TAHUN DI DESA SITUDAUN KABUPATEN BOGOR
}

\author{
Nining Fitrianingsih ${ }^{1}$, Tisna Yanti ${ }^{2^{*}}$, Ludfi Putra Madienda ${ }^{3}$ \\ ${ }^{1,2}$ Dosen sekolah tinggi kesehatan wijaya husada \\ ${ }^{3}$ Mahasiswa sekolah tinggi kesehatan wijaya husada \\ Email Koresponden: ludfiputramadienda@gmail.com
}

\section{ABSTRACT: CORRELATION BETWEEN BETWEEN MATERNAL KNOWLEDGE ABOUT NUTRITION WITH PROTEIN ENERGY LACK IN CHILDREN AGED 2-5 YEARS IN SITUDAUN VILLAGE, BOGOR REGENCY}

Background of study: PEM (Less Protein Energy) is one of the most important nutritional disorders in Indonesia and other developing countries. PE patients have various pathological conditions caused by lack of energy and protein in varying proportions. PEM disease was given an international name, namely Calory Protein Malnutrition (CPM), then converted into Protein Energy Malnutrition (PEM). This disease began to be widely investigated in Africa, and in that continent PEM is known by the local name kwashiorkhor which means red hair disease.

Objective: To be able to know the description of mother's knowledge about nutrition for toddlers on things that support nutrition improvement and its relationship with the state of Protein Energy Deficiency in children 24-60 months at Posyandu Melati II Kp. Pasir Ipis Situdaun Village, Tenjolaya District, Bogor Regency and the factors that influence it.

Research Methods: This research is primary data using an observational approach with a cross sectional study design (cross-sectional). This analysis is used to determine whether or not there is a relationship between the two variables using the Chi-Square (X2) test because the dependent and independent variables are categories with a $95 \%$ confidence level.

Research Results: It can be seen from 79 respondents that the mother's level of knowledge is mostly 40 people (50.6\%), and a small portion as many as 39 people (49.4\%) in Posyandu Melati II, Situdaun Tenjolaya Village, Bogor Regency. And $p$ value $0.00(<0.05)$. Indicates that there is a significant relationship between the mother's level of knowledge about nutrition and the incidence of protein energy deficiency in children aged 2-5 years.

Conclusion: There is a significant correlation between the level of knowledge of mothers about nutrition with the incidence of protein energy deficiency in children aged 2-5 years in the village of situdaun, Bogor district, with $p$-value = 0.000 .

Keywords: Mother's knowledge about nutrition, Protein Energy Lack, Children 
INTISARI: HUBUNGAN TINGKAT PENGETAHUAN IBU TENTANG GIZI DENGAN KEJADIAN KURANG ENERGI PROTEIN PADA ANAK USIA 2-5 TAHUN DI DESA SITUDAUN KABUPATEN BOGOR

Latar Belakang: KEP (Kurang Energi Protein) merupakan salah satu penyakit gangguan gizi yang penting di Indonesia maupun di negara yang sedang berkembang lainnya. Penderita KEP memiliki berbagai macam keadaan patologis yang disebabkan oleh kekurangan energi maupun protein dalam proporsi yang bermacam-macam. Penyakit KEP diberi nama secara internasional yaitu Calory Protein Malnutrition (CPM), kemudian diubah menjadi Protein Energy Malnutrition (PEM). Penyakit ini mulai banyak diselidiki di Afrika, dan di benua tersebut KEP dikenal dengan nama lokal kwashiorkhor yang berarti penyakit rambut merah.

Tujuan: Untuk dapat Mengetahui gambaran pengetahuan ibu tentang gizi balita terhadap hal hal yang mendukung perbaikan gizi dan hubungannya dengan keadaan Kurang Energi Protein pada anak 24 - 60 bulan di Posyandu Melati II Kp. Pasir Ipis Desa Situdaun Kecamatan Tenjolaya, Kabupaten Bogor serta faktor yang mempengaruhinya.

Metode Penelitian: Penelitian ini merupakan data primer dengan menggunakan pendekatan observasional dengan desain studi cross sectional (potong lintang). analisis ini digunakan untuk mengetahui ada atau tidaknya hubungan antara dua variebel tersebut dengan menggunakan uji Chi-Square $\left(\mathrm{X}^{2}\right)$ karena variabel dependen dan independennya adalah kategori dengan tingkat kepercayaan $95 \%$. Hasil Penelitian: Didapatkan dapat diketahui dari 79 responden bahwa tingkat penegtahuan ibu sebagian besar 40 orang $(50.6 \%)$, dan sebagian kecil sebanyak 39 orang (49.4\%) di Posyandu Melati II Desa Situdaun Tenjolaya Kabupaten Bogor. Dan $p$ value $0.00(<0.05)$. Menandakan adanya hubungan yang significant antara hubungan tingkat pengetahuan ibu tentang gizi dengan kejadian kurang energi protein pada anak usia 2-5 tahun.

Kesimpulan: Terdapat korelasi yang bermakna antara hubungan tingkat pengetahuan ibu tentang gizi dengan kejadian kurang energi protein pada anak usia 2-5 tahun di desa situdaun kabupaten bogor, dengan $p$-value $=0.000$.

Kata Kunci: Pengetahuan Ibu tentang gizi, Kurang Energi Protein , Anak

\section{PENDAHULUAN}

KEP (Kurang Energi Protein) merupakan salah satu penyakit gangguan gizi yang penting di Indonesia maupun di negara yang sedang berkembang lainnya. Prevalensi tertinggi terdapat pada anak-anak balita, ibu yang sedang mengandung dan menyusui. Penderita KEP memiliki berbagai macam keadaan patologis yang disebabkan oleh kekurangan energi maupun protein dalam proporsi yang bermacam-macam. Akibat kekurangan tersebut timbul keadaan KEP pada derajat yang ringan sampai yang berat (Adriani dan Wijatmadi, 2012).

Penyakit KEP diberi nama secara internasional yaitu Calory Protein Malnutrition (CPM), kemudian diubah menjadi Protein Energy Malnutrition (PEM). Penyakit ini mulai banyak diselidiki di Afrika, dan di benua tersebut KEP dikenal dengan nama lokal kwashiorkhor yang berarti penyakit rambut merah. Masyarakat di tempat tersebut menganggap kwashiorkhor sebagai kondisi yang biasa terdapat pada 
anak kecil yang sudah mendapat adik. (Adriani dan Wijatmadi, 2012). Menurut Arisman (2004) Kurang Energi Protein (KEP) akan terjadi disaat kebutuhan tubuh akan kalori, protein, atau keduanya tidak tercukupi oleh diet. Kedua bentuk defisiensi ini tidak jarang berjalan bersisian, meskipun salah satu lebih dominan daripada yang lain. Sedangkan menurut Merryana Adriani dan Bambang Wijatmadi (2012) KEP merupakan keadaan kurang gizi yang disebabkan oleh rendahnya konsumsi energi dan protein dalam makanan sehari-hari sehingga tidak memenuhi kecukupan yang dianjurkan.

Kurang Energi Protein (KEP) didefinisikan suatu keadaan kurang gizi yang disebabkan oleh rendahnya konsumsi energi dan protein dalam makanan sehari-hari sehingga tidak memenuhi Angka Kecukupan Gizi (AKG) dalam jangka waktu yang lama yang ditandai dengan z-skor berat badan berada di bawah -2.0 SD baku normal (Kemenkes 2010). KEP pada anak balita, masih menjadi salah satu masalah gizi di berbagai wilayah Indonesia termasuk di Provinsi Jawa Barat. Secara nasional prevalensi balita kurang gizi dan gizi buruk sebesar $21 \%$ dan di Jawa Barat sebesar 18,7 \% pada tahun 2017 (RI, 2017). Fenomena anak KEP atau “gagal tumbuh" pada anak Indonesia mulai terjadi pada usia 4 - 6 bulan karena bayi diberikan MP-ASI (Makanan Pendamping-ASI) yang tidak tepat.

Berdasarkan gejalanya, KEP dibagi menjadi dua jenis, yaitu KEP ringan dan KEP berat. Kejadian KEP ringan lebih banyak terjadi di masyarakat, KEP ringan sering terjadi pada anak-anak pada masa pertumbuhan. Gejala klinis yang muncul diantaranya adalah pertumbuhan linier terganggu atau terhenti, kenaikan berat badan berkurang atau terhenti, ukuran lingkar lengan atas (LILA) menurun, dan maturasi tulang terhambat. Nilai z-skor indeks berat badan menurut tinggi badan (BB/TB) juga menunjukkan nilai yang normal atau menurun, tebal lipatan kulit normal atau berkurang, dan biasanya disertai anemia ringan. Selain itu, aktivitas dan konsentrasi berkurang serta kadang disertai dengan kelainan kulit dan rambut (Par 2016).

Balita yang mengalami KEP akan mengalami gagal tumbuh (growth faltering) anak yang kekurangan gizi pada usia balita akan tumbuh pendek, dan mengalami gangguan pertumbuhan dan perkembangan otak yang berpengaruh pada rendahnya tingkat kecerdasan, karena tumbuh kembang otak $80 \%$ terjadi pada usia dini yaitu 3 tahun pertama. Masa ini sering juga disebut sebagai fase "Golden Age" (Soetjiningsih, 1995). Kurang gizi juga menyebabkan anakanak rentan terhadap serangan penyakit, seperti menderita radang paru-paru dan sesak nafas. Struktur sel-sel dalam tubuh tidak tumbuh sempurna padahal di masa balita inilah pertumbuhan badan anak, termasuk pertumbuhan sel-sel otak sedang dalam kondisi puncak. Meskipun kejadian KEP menjadi angka minoritas dibandingkan dengan yang tidak KEP, tetapi masih ada yang mengalami KEP berat dan ini tetap menjadi perhatian khusus mengingat dampak dari KEP itu sendiri (Aritonang, 2006).

Pada tahun 2013, 17\% atau 98 juta anak di bawah lima tahun di negara berkembang mengalami kurang gizi (berat badan rendah menurut umur berdasarkan standar WHO). Prevalensi tertinggi berada di wilayah Asia Selatan sebesar 30\%, diikuti Afrika Barat 21\%, Osceania dan Afrika Timur 2 19\%, Asia Tenggara dan Afrika Tengah 16\%, dan Afrika Selatan 12\% (WHO, 2014). 
Berdasarkan hasil Riset Kesehatan Dasar (Riskesdas) Kementerian Kesehatan 2018 menunjukkan 17,7\% bayi usia di bawah 5 tahun (balita) masih mengalami masalah gizi. Angka tersebut terdiri atas balita yang mengalami gizi buruk sebesar $3,9 \%$ dan yang menderita gizi kurang sebesar $13,8 \%$.

Jawa Barat berada pada peringkat ke-23 dari 34 provinsi dan memiliki angka 12,5\%, angka tersebut lebih tinggi dibanding DKI Jakarta yaitu $11,2 \%$ pada prevalensi kurang energi kronis yaitu (Riskesdas, 2018). Menurut data Dinas Kesehatan Provinsi Jawa Barat pada 2016, prevalensi kurus yang terjadi pada remaja umur $16-18$ tahun secara umum sebesar $9,1 \%$ (1,4\% sangat kurus dan 7,7\% kurus). Sebanyak 12 kabupaten/kota memiliki angka prevalensi kurus diatas prevalensi Jawa Barat, yaitu Kab. Sumedang, Kab. Bogor, Kab. Subang, Kab. Karawang, Kota Bekasi, Kab. Cirebon, Kab. Kuningan, Kota Banjar, Kota Sukabumi, Kota Bogor, Kab. Indramayu dan Kota Cirebon. Sedangkan pada tahun 2018 menunjukkan prevalensi risiko kurang energi kronis (KEK) pada WUS sebesar 20-30\% terjadi di Jawa Barat. Hasil tersebut menunjukkan bahwa prevalensi risiko kurang energi kronis (KEK) pada WUS masih tinggi salah satunya di Kabupaten Bogor.

Data terakhir Dinas

Kesehatan Kab. Bogor tahun 2018 pengidap gizi buruk terdapat 100 orang atau sekitar 0,0017 \% dari 577.656 balita. Laporan puskesmas Tenjolaya pada, tahun 2017 dengan kasus gizi buruk dari jumlah balita 4.201 sebanyak 19 anak balita atau $1,36 \%$ dan gizi kurang sebanyak 196 anak balita atau 3,31\% dan pada tahun 2019 dari jumlah balita 5.451 menunjukkan jumlah balita yang mengalami gizi buruk sebanyak 33 anak balita atau $1,60 \%$ dan gizi kurang sebanyak 213 anak balita atau $3,43 \%$, angka ini mengalami kenaikan yang cukup tinggi untuk provinsi Jawa Barat maupun Kab. Bogor itu sendiri (Dinas Kesehatan Kab. Bogor, 2018).

Berdasarkan penelitian yang dilaksanakan di Posyandu wilayah kerja Puskesmas Nusukan Surakarta Februari 2016. Pengambilan sampel dilakukan dengan teknik purposive sampling dengan menggunakan 47 sampel ibu berserta balita. Instrumentasi penelitian menggunakan, BB, TB, Umur, dan nilai Kuesioner Pengetahuan Ibu Tentang Perbaikan Status Gizi Anak Balita. Berdasarkan hasil uji statistik Chi square menunjukkan bahwa terdapat hubungan antara tingkat pengetahuan orang tua dengan status gizi anak di bawah 5 tahun dengan nilai $p<0,001$. Terdapat hubungan antara pengetahuan orang tua dengan status gizi anak di bawah 5 tahun di Posyandu Wilayah Kerja Puskesmas Nusukan Surakarta.

Untuk mengatasi anak balita kurang gizi memerlukan peranan penting dari keluarga, praktisi kesehatan, maupun pemerintah. Upaya penanggulangan gizi di Indonesia menurut Depkes RI secara garis besar adalah menurunkan prevalensi KEP pada balita dan tujuan tersebut mendukung upaya penurunan angka kematian balita. Upaya penanggulangan keempat masalah gizi utama tersebut dilaksanakan dalam bentuk pelayanan langsung terhadap kelompok sasaran, dan pelayanan secara tidak langsung di masyarakat. Pelayanan langsung kepada kelompok sasaran dilaksanakan dalam bentuk pelayanan gizi di Puskesmas dan pelayanan gizi di posyandu dengan sasaran khusus ibu dan anak. Sedangkan pelayanan tidak langsung di masyarakat dilaksanakan dalam bentuk penyuluhan gizi masyarakat. Upaya 
langsung dan tidak langsung untuk penanggulangan KEP dilaksanakan dengan memantapkan Usaha Perbaikan Gizi Keluarga (UPGK) (Beck, 2017).

Peranan ibu begitu dominan bagi kesehatan anak balita terutama dalam pemberian gizi yang cukup pada anak balita, menuntut ibu harus mengetahui dan memahami akan kebutuhan gizi pada anak, untuk itu yang harus dimiliki oleh ibu adalah pengetahuan tentang kebutuhan gizi balita. Pengetahuan ( knowledge) adalah sesuatu yang hadir dan terwujud dalam jiwa dan pikiran. seseorang dikarenakan adanya reaksi, persentuhan dan hubungan dengan lingkungan dan alam sekitarnya (Siregar, 2008).

Dari latar belakang diatas dapat dilihat bahwa masalah gizi merupakan masalah yang sangat rumit karena menyangkut berbagai faktor, dan untuk menanggulanginnya juga harus melibatkan sektor luar kesehatan sendiri. Anak dengan usia 24 - 60 bulan merupakan usia dimana anak sangat tergantung akan makanan tambahan dari orang tua. Bila keadaan ini tidak tercapai maka status gizi anak akan menurun, dan ini salah satu alasan mengapa prevalensi gizi buruk mulai tampak dan meninggi pada usia antara 2 sampai 5 tahun.

Peranan posyandu untuk mengedukasi ibu tentang gizi dalam pemberian makanan pada balita merupakan hal yang amat penting. Berdasarkan pemaparan diatas perlu dilakukan penelitian tentang hubungan antara pengetahuan ibu tentang gizi balita dengan kejadian kurang energi protein pada anak usia 24 - 60 bulan di Posyandu Melati II Kp. Pasir Ipis Desa Situdaun Kecamatan Tenjolaya Kota Bogor.

\section{METODE}

Jenis data yang digunakan yaitu kuantitatif dengan rancangan cross sectional yang bertujuan untuk mengetahui hubungan antara variabel bebas dan terikat, artinya variabel bebas dan terikat pada objek penelitian diukur dalam waktu yang bersamaan.

Penelitian ini merupakan data primer dengan menggunakan pendekatan observasional dengan desain studi cross sectional (potong lintang). Studi deskriptif korelasi ini berfungsi untuk mengetahui faktorfaktor yang berhubungan Pengetahuan Ibu Tentang Gizi dengan Kejadian Kurang Energi Protein pada anak usia 2-5 tahun di Posyandu Melati II Kp. Pasir Ipis Desa Situdaun Kecamatan Tenjolaya Kabupaten Bogor,.

Dalam penelitian ini akan ditelusuri keteraturan dalam kunjungan ke Posyandu dengan kejadian Kurang Energi Protein pada anak usian 2-5 tahun, serta faktor apa saja yang mempengaruhi Keadaan bayi dengan Kurang Energi Protein.

sampel yang diikut sertakan adalah ibu yang mempunyai bayi kurang dari 60 bulan di Posyandu Melati II Kp. Pasir Ipis Desa Situdaun Kecamatan Tenjolaya Kabupaten Bogor. Untuk mengetahui jumlah sampel minimal yang harus dikumpulkan di wilayah penelitian digunakan rumus acak sederhana dan mengalikan hasil perhitungan.

\section{HASIL}

Di dalam Penelitian mencakup pengetahuan ibu tentang gizi dan kejadian kurang energi protein.

Berdasarkan data Puskesmas Tenjolaya pada, tahun 2017 dengan kasus gizi buruk dari jumlah balita 4.201 sebanyak 19 anak balita atau 
1,36\% dan gizi kurang sebanyak 196 anak balita atau 3,31\%.

Analisa ini digunakan untuk mendapatkan gambaran distribusi frekuensi dari variabel bebas dan variabel terikat untuk mengetahui variasi dari masing masing variabel. Untuk membuktikan hipotesis digunakan analisa bivariat.

a. Distribusi Frekuensi

Pengetahuan Tentang Gizi

Distribusi Frekuensi Pengetahuan Ibu Tentang Gizi di Posyandu Melati II Desa Situdaun Tenjolaya Kabupaten Bogor

\begin{tabular}{llll}
\hline $\begin{array}{l}\text { N } \\
\text { o }\end{array}$ & $\begin{array}{l}\text { Pengeta } \\
\text { huan }\end{array}$ & $\begin{array}{l}\text { Freque } \\
\text { ncy } \\
\text { (peopl } \\
\text { e) }\end{array}$ & $\begin{array}{l}\text { Persen } \\
\text { tase } \%\end{array}$ \\
\hline 1 & 2 & 3 & 4 \\
\hline 1 & Baik & 41 & 51.9 \\
\hline 2 & Cukup & 38 & 48.1 \\
\hline 3 & Total & 79 & 100 \\
\hline
\end{tabular}

Berdasarkan tabel 1 di atas dapat diketahui dari 79 responden bahwa tingkat penegtahuan ibu sebagian besar baik 41 orang (51.9\%), dan sebagian kecil sebanyak 38 orang (48.1\%) di Posyandu Melati II Desa Situdaun Tenjolaya Kabupaten Bogor

a. Distribusi Frekuensi Kurang Energi Protein (KEP)

Tabel. 2

Distribusi Frekuensi Pengetahuan Ibu Tentang Gizi di Posyandu Melati II Desa Situdaun Tenjolaya Kabupaten Bogor

\begin{tabular}{llll}
\hline $\mathbf{N}$ & $\begin{array}{l}\text { Pengetah } \\
\text { o }\end{array}$ & $\begin{array}{l}\text { Fan } \\
\text { ncy } \\
\text { (people } \\
\text { ) }\end{array}$ & $\begin{array}{l}\text { Persent } \\
\text { ase } \%\end{array}$ \\
\hline 1 & 2 & 3 & 4 \\
\hline 1 & Cukup & 33 & 41.8 \\
\hline 2 & Kurang & 46 & 58.2 \\
\hline 3 & Total & 79 & 100 \\
\hline
\end{tabular}

Berdasarkan tabel 4.2 di atas dapat diketahui dari 79 responden bahwa tingkat pengetahuan ibu sebagian besar 33 orang (41.8\%), dan sebagian kecil sebanyak 46 orang (58.2\%) di Posyandu Melati II Desa Situdaun Tenjolaya Kabupaten Bogor

\section{Analisa Bivariat}

Merupakan tabel silang antara dua variabel yaitu variabel dependen keadaan Kekurangan Energi Protein dan variabel independen kedatangan ibu ke posyandu untuk menimbangkan berat badan bayinya serta variabel lain yang mempengaruhi kejadian KEP (yang meliputi pendidikan ibu, pekerjan ibu, pendidikan ayah, pekerjaan ayah, pendapatan, jumlah anggota keluarga, jumlah balita, umur anak terakhir, dan anak pernah mengalami sakit satu bulan terakhir. analisis ini digunakan untuk mengetahui ada atau tidaknya hubungan antara dua variebel tersebut dengan menggunakan uji Chi-Square $\left(\mathrm{X}^{2}\right)$ karena variabel dependen dan independennya adalah kategori dengan tingkat kepercayaan $95 \%$.

a. Hubungan Pengetahuan Ibu Tentang Gizi dengan Kejadian Kurang Energi Protein.

Tabel. 3

Distribusi Frekuensi Pengetahuan Ibu Tentang Gizi di Posyandu Melati II Desa Situdaun Tenjolaya Kabupaten Bogor

\begin{tabular}{llll}
\hline $\mathbf{N}$ & $\begin{array}{l}\text { Pengeta } \\
\text { huan }\end{array}$ & $\begin{array}{l}\text { Freque } \\
\text { ncy } \\
\text { (peopl } \\
\text { e) }\end{array}$ & $\begin{array}{l}\text { Persen } \\
\text { tase \% }\end{array}$ \\
\hline 1 & 2 & 3 & 4 \\
\hline 1 & Cukup & 37 & 46.8 \\
\hline 2 & Kurang & 42 & 53.2 \\
\hline 3 & Total & 79 & 100 \\
\hline
\end{tabular}

Berdasarkan tabel 3 di atas dapat diketahui dari 79 responden bahwa tingkat penegtahuan ibu sebagian 
besar 37 orang (46.8\%), dan sebagian kecil sebanyak 42 orang (53.2\%) di Posyandu Melati II Desa Situdaun Tenjolaya Kabupaten Bogor

a. Hubungan Pengetahuan Ibu Tentang Gizi dengan Kejadian Kurang Energi Protein anak usia 2-5 tahun.

Tabel. 4.4

Distribusi Frekuensi Pengetahuan Ibu Tentang Gizi di Posyandu Melati II Desa Situdaun Tenjolaya Kabupaten Bogor

\begin{tabular}{llll}
\hline $\mathbf{N}$ & $\begin{array}{l}\text { Pengeta } \\
\text { huan }\end{array}$ & $\begin{array}{l}\text { Freque } \\
\text { ncy } \\
\text { (peopl } \\
\text { e) }\end{array}$ & $\begin{array}{l}\text { Persen } \\
\text { tase } \%\end{array}$ \\
\hline 1 & 2 & 3 & 4 \\
\hline 1 & Cukup & 40 & 50.6 \\
\hline 2 & Kurang & 39 & 49.4 \\
\hline 3 & Total & 79 & 100 \\
\hline
\end{tabular}

Berdasarkan tabel 4.4 di atas dapat diketahui dari 79 responden bahwa tingkat penegtahuan ibu sebagian besar 40 orang (50.6\%), dan sebagian kecil sebanyak 39 orang $(49.4 \%)$ di Posyandu Melati II Desa Situdaun Tenjolaya Kabupaten Bogor.

\section{PEMBAHASAN}

1. Interprestasi dan pembahasan penelitian

Pembahasan hasil penelitian di uraikan satu persatu dari variabel independennya pengetahuan dan variabel dependennya yaitu Kurang Energi Protein (KEP), sebagai berikut:

a. Pengetahuan

Berdasarkan tabel $4.1 \mathrm{di}$ atas dapat diketahui dari 79 responden bahwa tingkat penegtahuan ibu sebagian besar baik 41 orang (51.9\%), dan sebagian kecil sebanyak 38 orang (48.1\%) di Posyandu Melati II Desa Situdaun Tenjolaya Kabupaten Bogor.

Dengan demikian dapat disimpulkan bahwa hasil pengetahuan ibu tentang status gizi sesuai dengan pendapat Notoatmodjo (2007), bahwa pengetahuan merupakan hasil dari tahu, dan hal ini terjadi setelah orang melakukan penginderaan terhadap suatu obyek, baik bertanya pada tenaga kesehatan maupun membaca buku referensi kesehatan anak.

Menurut penelitian di Desa Penusupan Kecamatan Pangkah Kabupaten Tegal Tahun 2013 diketahui bahwa sebagian besar balita berstatus gizi baik $(73,1 \%)$, hal ini didukung oleh kesadaran masyarakat untuk menjadi keluarga yang sehat yang sadar gizi dan melaksanakan perilaku hidup bersih dan sehat.

b. Kurang Energi Protein (KEP)

Berdasarkan tabel 4.2 di atas dapat diketahui dari 79 responden bahwa tingkat pengetahuan ibu sebagian besar 33 orang $(41.8 \%)$, dan sebagian kecil sebanyak 46 orang (58.2\%) di Posyandu Melati II Desa Situdaun Tenjolaya Kabupaten Bogor.

Menurut penelitian di Desa Penusupan Kecamatan Pangkah Kabupaten Tegal Tahun 2013 diketahui bahwa sebagian besar balita berstatus gizi baik $(73,1 \%)$, hal ini didukung oleh kesadaran masyarakat untuk menjadi keluarga yang sehat yang sadar gizi dan melaksanakan perilaku hidup bersih dan sehat.

Dengan demikian hasil ini sesuai dengan pendapat Supariasa (2001), keadaan gizi adalah akibat dari keseimbangan antara konsumsi dan penyerapan zat gizi dan penggunaan zat-zat gizi tersebut, yang berdampak pada status gizi anak.

c. Berdasarkan tabel 4.4 di atas dapat diketahui dari 79 responden bahwa tingkat penegtahuan ibu sebagian besar 40 orang $(50.6 \%)$, dan sebagian kecil sebanyak 39 orang $(49.4 \%)$ di Posyandu Melati II Desa Situdaun Tenjolaya Kabupaten Bogor. Dan p value $0.00 \quad(<0.05)$. Menandakan 
adanya hubungan yang significant antara hubungan tingkat pengetahuan ibu tentang gizi dengan kejadian kurang energi protein pada anak usia 2-5 tahun.

Hasil penelitian di Desa Penusupan Kecamatan Pangkah Kabupaten Tegal yang dilakukan pada bulan Juni tahun 2013, tentang hubungan antara tingkat pengetahuan gizi dengan status gizi balita didapatkan bahwa tingkat pengetahuan ibu tentang gizi mempengaruhi terhadap status gizi balita $(p=0.007$ dan $x 2=14,247)$.

Berdasarkan hal tersebut maka dapat disimpulkan bahwa semakin baik pengetahuan responden tentang status gizi maka berakibat pada status gizi anak yang baik, karena responden dengan pengetahuan yang baik, responden akan memberikan makanan yang memenuhi nutrisi balita.

Sesuai teori tentang perilaku menurut Notoatmodjo (2007), sebelum orang mengadopsi perilaku baru dalam diri orang tersebut terjadi proses yang berurutan meliputi kesadaran, ketertarikan, menimbang-nimbang, mencoba dan beradaptasi. Kesadaran yang kurang, sehingga masih ada responden yang tidak memberikan makanan yang bergizi yang sesuai dengan umurnya dan bergizi seimbang.

\section{Keterbatasan Penelitian}

Pelaksanaan Penelitian ini tidak terlepas dari kelemahan-kelemahan yang terjadi, serta kemungkinan bias yang tidak terhindarkan, walaupun telah di upayakan untuk mengatasinya. Adapun kelemahan tersebut adalah :

1. Penelitian ini menggunakan cross sectional, penelitian dilakukan hanya satu kali pada waktu yang bersamaan. Artinya bahwa pengukuran semua variabel dilakukan secara bersamaan. Tehnik penelitian dilakukan dengan memberikan kuesioner dengan memberikan pertanyaan tentang variabel yang di teliti dan di sisi sendiri oleh responden tanpa ada intervensi dari peneliti.

2. Terjadi bias dimungkinkan karena faktor kesalahan interprestasi responden dalam menangkap maksud dari pertanyaan yang sebenarnya. Sehingga berdampak ketidaksesuaian antara jawaban dengan pertanyaan yang diajukan.

3. Masih ada beberapa responden pada saat mengisi kuesioner masih takut untuk menjawab dengan sebenarnya, karena ada kekawatiran/ rasa malu takut di ketahui orang lain dan akan berdampak pada nama baik.

\section{Implikasi Terhadap Lahan Penelitian}

1. Bagi Posyandu Melati II.

Hasil penelitian ini bisa menjadi masukan bagi petugas Nakes, masyarakat di Kp.Pasir Ipis Desa Situdaun Kecamatan Tenjolaya Kabupaten Bogor.

2. Bagi Peneliti

a. Memberikan pengalaman dan kemampuan dalam meneliti dan menganalisa di lingkungan masyarakat sekitar Posyandu Melati II .

b. Dapat mengaplikasikan ilmu yang telah di dapat dari bangku perkuliahan.

c. Bagi STIKes Wijaya Husada Bogor Dapat di jadikan sebagai bahan acuan bagi mahasiswa STIKes Wijaya Husada Bogor selanjutnya.

\section{KESIMPULAN}

KEP (Kurang Energi Protein) merupakan salah satu penyakit gangguan gizi yang penting di Indonesia maupun di negara yang sedang berkembang lainnya. Prevalensi tertinggi terdapat pada anak-anak balita, ibu yang sedang mengandung dan menyusui. 
Penderita KEP memiliki berbagai macam keadaan patologis yang disebabkan oleh kekurangan energi maupun protein dalam proporsi yang bermacam-macam. Akibat kekurangan tersebut timbul keadaan KEP pada derajat yang ringan sampai yang berat (Adriani dan Wijatmadi, 2012).

1. Tingkat penegtahuan ibu sebagian besar baik 41 orang (51.9\%), dan sebagian kecil sebanyak 38 orang (48.1\%) di Posyandu Melati II Desa Situdaun Tenjolaya Kabupaten Bogor.

2. Tingkat pengetahuan ibu sebagian besar 33 orang $(41.8 \%)$, dan sebagian kecil sebanyak 46 orang $(58.2 \%)$ di Posyandu Melati II Desa Situdaun Tenjolaya Kabupaten Bogor.

3. Tingkat penegtahuan ibu sebagian besar 40 orang $(50.6 \%)$, dan sebagian kecil sebanyak 39 orang $(49.4 \%)$ di Posyandu Melati II Desa Situdaun Tenjolaya Kabupaten Bogor. Dan p value $0.00 \quad(<0.05)$. Menandakan adanya hubungan yang significant antara hubungan tingkat pengetahuan ibu tentang gizi dengan kejadian kurang energi protein pada anak

usia 2-5 tahun.

\section{Saran}

1. Posyandu Melati II Kp.Pasir Ipis Desa Situdaun Tenjolaya Bogor

Hasil Penelitian ini bisa menjadi masukan bagi yang berkepentingan/ Staekholder (Petugas Medis yang bertugas di desa Situdaun, Kepala Desa Situdaun, Puskesmas Tenjolaya Kabupaten Bogor), untuk berupaya (menekan/ menghilangkan kejadian KEP khususnya di Posyandu Melati II dan umumnya di desa Situdaun).
2. Bagi STIKes Wijaya Husada Bogor Dapat dijadikan bahan acuan bagi mahasiswa STIKes Wijaya Husada Bogor yang akan melakukan penelitian selanjutnya.

\section{DAFTAR PUSTAKA}

Depkes RI. (2002). Pedoman Deteksi Tumbuh Kembang Balita. Jakarta:Direktorat jendral Pembinaan Kesehatan masyarakat Direktorat Bina Kesehatan masyarakat.

DepKes RI. (2002). Program Perbaikan Gizi Makro. Jakarta: Direktorat Gizi Masyarakat, Depkes RI.

DepKes RI. (2007). Pedoman Pelaksanaan Stimulasi, Deteksi dan Intervensi Dini Tumbuh Kembang Anak Ditingkat Pelayanan Kesehatan. Jakarta: DepKes.

Departeman Gizi dan Kesehatan Masyarakat Fakultas Kesehatan Masyarakat Universitas Indonesia.(2007). Gizi dan Kesehatan Masyarakat. Jakarta : Rajawali Press.

Balitbang Kemenkes RI. (2018). Riset Kesehatan Dasar; Riskesdes. Jakarta: Balitbang Kemenkes RI.

Arikunto, S. (2006). Prosedur Penelitian Suatu Pendekatan Praktik Edisi Revisi VI. Jakarta: PT Rineka Cipta. 